\title{
Dye decolorization and detoxification potential of Ca-alginate beads immobilized manganese peroxidase
}

\author{
Muhammad Bilal ${ }^{*}$ and Muhammad Asgher
}

\begin{abstract}
Background: In view of compliance with increasingly stringent environmental legislation, an eco-friendly treatment technology of industrial dyes and effluents is a major environmental challenge in the color industry. In present study, a promising and eco-friendly entrapment approach was adopted to immobilize purified manganese peroxidase (MnP) produced from an indigenous strain of Ganoderma lucidum IBL-05 on Ca-alginate beads. The immobilized MnP was subsequently used for enhanced decolorization and detoxification of textile reactive dyes).

Results: $\mathrm{MnP}$ isolated from solid-state culture of G. Iucidum IBL-05, presented highest immobilization yield (83.9 $\%)$ using alginate beads prepared at optimized conditions of $4 \%(\mathrm{w} / \mathrm{v})$ sodium alginate, $2 \%(\mathrm{w} / \mathrm{v})$ Calcium chloride $\left(\mathrm{CaCl}_{2}\right)$ and $0.5 \mathrm{mg} / \mathrm{ml}$ enzyme concentration. Immobilization of MnP enhanced optimum temperature but caused acidic shift in optimum pH of the enzyme. The immobilized MnP showed optimum activity at pH 4.0 and $60{ }^{\circ} \mathrm{C}$ as compared to $\mathrm{pH} 5.0$ and $35^{\circ} \mathrm{C}$ for free enzyme. The kinetic parameters $K_{m}$ and $V_{\max }$ of MnP were significantly improved by immobilization. The enhanced catalytic potential of immobilized MnP led to 87.5\%, $82.1 \%, 89.4 \%, 95.7$ $\%$ and $83 \%$ decolorization of Sandal-fix Red $C_{4} B L N$, Sandal-fix Turq Blue GWF, Sandal-fix Foron Blue E $E_{2} B L N$, Sandal-fix Black CKF and Sandal-fix Golden Yellow CRL dyes, respectively. The insolubilized MnP was reusable for 7 repeated cycles in dye color removal. Furthermore, immobilized MnP also caused a significant reduction in biochemical oxygen demand (BOD) (94.61-95.47\%), chemical oxygen demand (COD) (91.18-94.85\%), and total organic carbon (TOC) (89.58-95\%) of aqueous dye solutions.

Conclusions: G. lucidum MnP was immobilized in Ca-alginate beads by entrapment method to improve its practical effectiveness. Ca-alginate bound MnP was catalytically more vigorous, thermo-stable, reusable and worked over wider ranges of $\mathrm{pH}$ and temperature as compared to its free counterpart. Results of cytotoxicity like hemolytic and brine shrimp lethality tests suggested that Ca-alginate immobilized MnP may effectively be used for detoxification of dyes and industrial effluents.
\end{abstract}

Keywords: Ganoderma lucidum, Manganese peroxidase, Immobilization, Reactive dyes, Decolorization, Cytotoxicity

\section{Background}

Synthetic dyes are extensively used in textile, paper, cosmetic, pharmaceutical, dyeing and printing industries. The disposal of dye containing industrial effluents into receiving water bodies' triggers serious environmental and health hazards [1-5]. Among various groups of dyes, reactive dyes are the most problematic, as their complex

\footnotetext{
* Correspondence: bilaluaf@hotmail.com

Industrial Biotechnology Laboratory, Department of Biochemistry, University of Agriculture, Faisalabad, Pakistan
}

aromatic structures are resistant to bio-degradation [6]. Such scenario has created great concern among industrialdescribed for decolorization of cost, low efficiency, secondary pollution, residues waste problem and inapplicability to treat a wide variety of dyes, these methods are regarded economically un-acceptable 
for large-scale effluent treatment $[5,7]$. These facts certainly demand the development of an efficient, cost effective and green technology for decolorization and detoxification of dyes and industrial effluents. Biological approach using ligninolytic system of white rot fungi (WRF) seems to be the most potential alternative than traditional physico-chemical methods [8-10].

Ganoderma lucidum is an efficient lignin degrading WRF that produces considerable activities of ligninolytic enzymes, particularly manganese peroxidase $(\mathrm{MnP})$. Among the potential applications of $\mathrm{MnP}$ are bioremediation, biomass delignification, biopulping, biosensor development, textile finishing and wine stabilization $[2,11]$. Despite their great potential, the use of native microbial enzymes suffers certain restrictions under industrial process conditions. To circumvent these limitations, several strategies including mutations, genetic engineering, chemical modifications of amino acid residues and immobilization have been suggested. Enzyme immobilization appears to be an attractive approach to develop efficient biocatalyst with improved performances such as enhanced resistance to thermal and chemical inactivation, remarkable storage and operational stabilities, short response time and high reproducibility $[12,13]$.

In recent past, various immobilization supports like macroporous exchange resins, Ca-alginate beads, chitosan beads, polyvinyl alcohol, nanoporous silica gel, polyacrylamide and hydrophobic sol-gels have been used for MnP immobilization [14]. Entrapment in calcium alginate beads is of particular interest because of very mild and simple preparation conditions, non-toxicity, low cost and best performance [15]. Indeed, Alginate is a natural anionic poly-saccharide composed of repeated units of $\alpha$-L-guluronic acid and $\beta$-D-mannuronic acid residues. Alginate supports are usually prepared by cross linking of guluronic acid with mannuronic acid residues in the presence of divalent cations like $\mathrm{Ca}^{2+}, \mathrm{Ba}^{2+}, \mathrm{Co}^{2+}[16]$.

In the present study, MnP from G. lucidum IBL-05 was immobilized into $\mathrm{Ca}$-alginate beads and the conditions for immobilization and characterization of free and immobilized enzyme were investigated. The reusability, thermal and storage stability of immobilized $\mathrm{MnP}$ were also studied and compared with free enzyme. In addition, the capability of both free and immobilized MnP to decolorize different textile dyes (Sandal reactive dyes) was assessed. The treatment efficiency was evaluated on the basis of decolorization, water quality parameters (BOD, COD, TOC) and cytotoxicity (erythrocytes lysis and brine shrimp lethality) reduction.

\section{Methods}

\section{Chemicals and dyes}

Coomassie Brilliant Blue G-250, sodium dodecylsulphate, Sephadex G-100, N, N, N', N'-tetra-methylethylenediamine, $\beta$-mercaptoethanol, trizma base, sodium alginate, calcium chloride dihydrate $\left(\mathrm{CaCl}_{2}, 2 \mathrm{H}_{2} \mathrm{O}\right)$ and glutaraldehyde from Sigma chemicals (St. Louis, USA) were supplied by local suppliers. Triton X-100 and cyclophosphamide were purchased from Merck (Germany) and Scharlau (Spain), respectively. All chemicals and reagents were of analytical grade and used without further purification. Five Sandal Reactive textile dyes including Sandal-fix Red $\mathrm{C}_{4} \mathrm{BLN}$, Sandal-fix Turq Blue GWF, Sandalfix Foron Blue $E_{2} B L N$, Sandal-fix Black CKF and Sandalfix Golden Yellow CRL were generously gifted by Sandal Dye-stuffs Faisalabad, Pakistan. Characteristics of selected dyes have been presented in Table 1 .

\section{Preparation of lignocellulosic substrate}

Agro-industrial waste material wheat bran collected from a local wheat mill of Faisalabad, Pakistan was sun dried followed by oven drying at $60{ }^{\circ} \mathrm{C}$ to constant weight. The dried substrate was pulverized to $0.45-0.90$ $\mathrm{mm}$ meshes in grinder (Ashraf Herbal Laboratories, Faisalabad) and stored in airtight plastic jars.

\section{Microorganism and inoculum development}

A pure culture of locally isolated fungal strain G. lucidum IBL-05 was maintained on potato dextrose agar (PDA) slants and preserved in the culture collection of Industrial Biotechnology Laboratory, Department of Biochemistry, University of Agriculture; Faisalabad). Kirk's basal medium supplemented with $1 \%$ (w/v) Millipore filtered sterile glucose solution was used as inoculum medium [11]. The medium constituents were $(\mathrm{g} / \mathrm{L})$ : ammonium tartrate, $0.22 ; \mathrm{KH}_{2} \mathrm{PO}_{4}, 0.21 ; \mathrm{MgSO}_{4} \cdot 7 \mathrm{H}_{2} \mathrm{O}$, $0.05 ; \mathrm{CaCl}_{2} \cdot \mathrm{H}_{2} \mathrm{O}, 0.01$; thiamine, 0.001 and tween-80 $(10 \mathrm{ml} / \mathrm{L})$. The $\mathrm{pH}$ of the medium was adjusted to 4.5

Table 1 Characteristics of Sandal reactive dyes used in immobilized MnP catalyzed decolorization studies

\begin{tabular}{lllll}
\hline Dyes & Color & $\lambda_{\max }$ & Class & CI Number \\
\hline Sandal-fix Red C ${ }_{4}$ BL & Red & 540 & Reactive & Reactive Red 195A \\
Sandal-fix Turq Blue GWF & Blue & 664 & Reactive & Reactive Blue 21 \\
Sandal-fix Golden Yellow CRL & Yellow & 414 & Reactive & Reactive Yellow 145A \\
Sandal-fix Black CKF & Black & 598 & Reactive & Mixture \\
Sandal-fix Foron Blue $E_{2}$ BLN & Foron Blue & 560 & Reactive & Not known \\
\hline
\end{tabular}


using $1 \mathrm{M} \mathrm{HCL} / 1 \mathrm{M} \mathrm{NaOH}$ and sterilized in autoclave (Sanyo, Japan) at $121{ }^{\circ} \mathrm{C}$ for $15 \mathrm{~min}$. G. lucidum IBL-05 from slant culture was aseptically transferred to the sterilized medium in laminar air flow (Dalton, Japan). The inoculated flask was incubated at $30{ }^{\circ} \mathrm{C}$ for 5 days in an orbital shaker (Sanyo-Gallenkamp, UK) with continuous shaking $(120 \mathrm{rpm})$ to obtain homogenous spore suspension $\left(1 \times 10^{7}\right.$ spores $\left./ \mathrm{ml}\right)$. The spore counting was performed using haemocytometer (Sigma-aldrich, USA).

\section{Production and extraction of $\mathrm{MnP}$}

Erlenmeyer flasks (triplicate), each containing $5 \mathrm{~g}$ wheat bran were moistened with Kirk's basal nutrient medium $(66 \% \mathrm{w} / \mathrm{w})$ at $\mathrm{pH} 4.5$ and cotton plugged. The flasks were sterilized in laboratory scale autoclave (Sanyo, Japan) and inoculated with $5 \mathrm{ml}\left(1 \times 10^{7}\right.$ spores $\left./ \mathrm{ml}\right)$ freshly prepared inoculums of G. lucidum IBL-05. The inoculated flasks were allowed to ferment in still culture incubator (Sanyo, Japan) at $30{ }^{\circ} \mathrm{C}$ for 5 days [19]. After 5 days, $100 \mathrm{ml}$ of distilled water was added to the fermented biomass and shaken for $30 \mathrm{~min}$ at $120 \mathrm{rpm}$ (Sanyo-Gallenkamp, UK). The contents of flasks were filtered, centrifuged (Eppendorf 5415C, Germany) and clear supernatants thus obtained were analyzed for $\mathrm{MnP}$ activity.

\section{Determination of $\mathrm{MnP}$ activity and protein contents}

$\mathrm{MnP}$ was assayed by a previously reported assay method [17]. Assay mixture $(2.6 \mathrm{ml})$ containing $1 \mathrm{ml}$ of $1 \mathrm{mM}$ $\mathrm{MnSO}_{4}, 1 \mathrm{ml}$ of $0.05 \mathrm{M}$ sodium malonate buffer ( $\mathrm{pH} 4.5$ ), $0.5 \mathrm{ml}$ of $\mathrm{H}_{2} \mathrm{O}_{2}$ and $0.1 \mathrm{ml}$ of enzyme solution was incubated at $25^{\circ} \mathrm{C}$ for $10 \mathrm{~min}$. Absorbance of each sample was measured at $270 \mathrm{~nm}\left(\varepsilon_{270}=11570 \mathrm{M} \mathrm{cm}^{-1}\right)$ in double beam UV/Visible spectrophotometer (HALO DB 20). Activity assay for immobilized enzyme was performed in the same conditions used for free enzyme, except that the reaction were maintained with stirring, and interrupted by separation of enzyme-immobilized beads from the reaction mixture by filtration in a Buchner funnel before the spectrophotometric readings. One unit of $\mathrm{MnP}$ activity $(\mathrm{U})$ is defined as the amount of enzyme capable of producing $1 \mu \mathrm{mol}$ of product in one min under the specified reaction conditions. The values obtained in the blank reactions were discounted from all readings. Bradford micro-assay [18] was followed for the determination of total protein contents in enzyme extract before and after every purification step. $10 \mu \mathrm{l}$ of enzyme sample was added to $1 \mathrm{ml}$ of Bradford reagent followed by incubation at $37{ }^{\circ} \mathrm{C}$ for $15 \mathrm{~min}$. The absorbance was read at $595 \mathrm{~nm}$ and protein was estimated from standard curve using Bovine Serum Albumin (BSA) as standard.

\section{Purification of MnP}

Four step purification procedure involving ammonium sulphate fractionation, dialysis, diethyl amino ethyl (DEAE) cellulose ion exchange and G-100 Sephadex gel filtration chromatography was employed for the purification of MnP. Crude MnP extract from G. lucidum IBL-05 was saturated by gradual addition of ammonium sulfate (up to $65 \%$ ), centrifuged and pellets were dissolved in $50 \mathrm{mM}$ Sodium Malonate buffer ( $\mathrm{pH} 4.5$ ), and dialyzed overnight against the same buffer. The dialyzate was subjected to ion exchange chromatography using DEAE-cellulose column. The column was equilibrated with phosphate buffer (pH 6.5) for $24 \mathrm{~h}$ and eluted with 0 to $1.0 \mathrm{M}$ linear gradient of $\mathrm{NaCl}$ in $50 \mathrm{mM}$ malonate buffer at a flow rate of $0.5 \mathrm{ml} / \mathrm{min}$. The MnP active fractions were pooled and loaded on Sephadex-G-100 column $(10 \times 300 \mathrm{~mm})$. A $50 \mathrm{mM}$ malonate buffer was used for elution (flow-rate $0.3 \mathrm{ml} / \mathrm{min}$ ) and positive fractions were collected, pooled and stored at $-20^{\circ} \mathrm{C}[19]$.

\section{Immobilization of $\mathrm{MnP}$}

The purified MnP was mixed with $4 \%$ sodium-alginate solution and $50 \mathrm{mM}$ sodium malonate buffer $(\mathrm{pH} 4.5)$ in 1:1:1 ratio [20]. To this mixture, $0.1 \mathrm{ml}$ gluteraldehyde solution $(0.8 \%$; v/v) was added and mixed gently. The resultant solution was extruded drop-wise into $\mathrm{CaCl}_{2}$ (200 mM) solution using a syringe needle to prepare uniform size beads. The beads were transferred to fresh $\mathrm{CaCl}_{2}$ solution and incubated for $30 \mathrm{~min}$ at $4{ }^{\circ} \mathrm{C}$. After $30 \mathrm{~min}$ of hardening, the beads were separated from $\mathrm{CaCl}_{2}$ solution by vacuum filtration and washed on a filter thrice with distilled water and finally with $50 \mathrm{mM}$ sodium malonate buffer ( $\mathrm{pH} 4.5)$. All the Ca-alginate beads were dried at $-70{ }^{\circ} \mathrm{C}$ under vacuum $(0.1 \mathrm{~mm} \mathrm{Hg})$ for $15 \mathrm{~h}$ followed by vacuum-drying at room temperature for $3 \mathrm{~h}$. Immobilization (\%) was determined according to the equation indicated below:

$\%$ immobilization $=\frac{\text { Total activity of immobilized enzyme }}{\text { Total activity of free enyme }} \times 100$

\section{Characterization of free and immobilized $\mathrm{MnP}$}

The free and Ca-alginate beads immobilized MnP were characterized by studying the following parameters:

\section{Effect of $\mathrm{pH}$}

In order to determine the $\mathrm{pH}$ optima for free and immobilized MnP, the reaction mixture was incubated for 15 min in buffers of $\mathrm{pH}$ 3.0-10.0. After incubation, the enzyme assay was performed using standard assay protocol. The buffers used were: tartrate-buffer, $\mathrm{pH}$ 3.0; sodium-malonate buffer, $\mathrm{pH} 4.0$; citrate-phosphate, $\mathrm{pH}$ 5.0, $\mathrm{pH}$ 6.0; sodium-phosphate, $\mathrm{pH} 7.0, \mathrm{pH} 8.0$ and carbonate-buffer of $\mathrm{pH} 9.0$ and 10.0. 


\section{Effect of temperature}

The free and immobilized MnP activity was tested at different temperatures $(30,35,40,45,50,55,60,65$ and $70{ }^{\circ} \mathrm{C}$ ) for $1 \mathrm{~h}$ at optimum $\mathrm{pH}$ before running the routine $\mathrm{MnP}$ assay.

\section{Effect of substrate concentration: Determination of kinetic parameters}

Effect of substrate concentration on activities of free and immobilized $\mathrm{MnP}$ was studied at optimum $\mathrm{pH}$ and temperature using varying concentrations of $\mathrm{MnSO}_{4}$ ranging from 0.1-1.0 mM. Lineweaver's-Burk reciprocal plots were constructed between $1 / \mathrm{S}$ and $1 / \mathrm{V}_{0}$ and kinetic parameters of Michaelis-Menten $\left(K_{\mathrm{m}}\right.$ and $\left.V_{\text {max }}\right)$ were determined.

\section{Decolorization of sandal reactive dyes}

A set of five Sandal reactive textile dyes was selected to investigate the decolorization potential of free and $\mathrm{Ca}$-alginate beads immobilized $\mathrm{MnP}$. Free and immobilized MnPs were transferred to 250-ml cotton plugged Erlenmeyer flasks (triplicate) containing $100 \mathrm{ml}$ of individual dye solution $(0.1 \mathrm{mg} / \mathrm{ml}), 1 \mathrm{~mL}$ of $1 \mathrm{mM} \mathrm{MnSO} 4,0.1 \mathrm{mM}$ $\mathrm{H}_{2} \mathrm{O}_{2}$ and Na-malonate buffer (50 mM; pH 4.5). Flasks were incubated at $35{ }^{\circ} \mathrm{C}$ on rotary shaker at $120 \mathrm{rpm}$ for $12 \mathrm{~h}$. After $12 \mathrm{~h}$, the contents of flasks were filtered, centrifuged $(8,000 \times g, 10 \mathrm{~min})$ and residual dye concentration was monitored at respective wavelengths of maximum absorbance (CE Cecil 7200, Germany) [3]. The decolorization efficiency of free and immobilized $\mathrm{MnP}$ for each dye was calculated using the relation given in equation 2. Where $\mathrm{A} i$ and $\mathrm{A} t$ are representing absorbance at zero and time $t$.

$$
\text { Decolorization }(\%)=\frac{A i-A t}{A i} \times 100
$$

\section{Stability studies}

\section{Thermal and storage stability}

Thermal stability was assayed by incubating free and immobilized MnPs simultaneously at $60{ }^{\circ} \mathrm{C}$ for $240 \mathrm{~min}$. Storage stability of both free and Ca-alginate immobilized MnPs was investigated for a period of 60 days at $25^{\circ} \mathrm{C}$ and the residual activity was monitored from time to time under standard assay conditions described above. Enzyme activity prior to incubation was defined as $100 \%$.

\section{Reusability}

Seven decolorization cycles of $12 \mathrm{~h}$ each were performed to test the reusability of Ca-alginate immobilized $\mathrm{MnP}$. At the end of each dye-decolorization cycle, Ca-alginate beads were filtered, washed three times with sodium malonate buffer $(50 \mathrm{mM})$ and replaced with fresh aqueous dye solutions. The activity of freshly prepared beads in the first run was defined as $100 \%$.

\section{Water quality parameters analysis}

The water quality parameters such as BOD, COD and TOC were measured for maximally decolorized dye solutions. BOD and COD values were monitored using BOD and COD meters (Lovibond, water testing systems). For TOC measurement, $2 \mathrm{~N} \mathrm{~K}_{2} \mathrm{Cr}_{2} \mathrm{O}_{7}(1 \mathrm{ml})$ and $\mathrm{H}_{2} \mathrm{SO}_{4}(1.6$ $\mathrm{ml}$ ) were taken in digestion flask containing dye samples (4 $\mathrm{ml}$ ) and the contents were digested for $1.5 \mathrm{~h}$ at $110{ }^{\circ} \mathrm{C}$, cooled and absorbance was monitored at $590 \mathrm{~nm}$.

\section{Cytotoxicity evaluation}

To evaluate free and Ca-alginate immobilized MnPs effect on cytotoxicity reduction, erythrocytes lysis and brine shrimp lethality tests were used [5]. The cytotoxicity of maximally decolorized dye solutions was investigated.

\section{Statistical analysis}

Mean and standard error (SE) values of the results from three replicates were calculated using Microsoft Excelsoftware (Microsoft) and the standard error (SE) values have been displayed as $\mathrm{Y}$-error bars in figures.

\section{Results and discussion}

\section{MnP production and purification}

A large magnitude of extracellular MnP $(717.7 \pm 2.3 \mathrm{U}$ $\mathrm{mL}^{-1}$ ) was produced from a locally isolated WRF strain G. lucidum IBL-05, grown on wheat bran as described in "Materials and Methods". The cell-free crude MnP extract was purified by using a four step procedure involving ammonium sulphate fractionation, dialysis, ion exchange and gel filtration chromatography as summarized in Table 2 [21]. Previously, the purification of various fungal protease, cellulases and ligninolytic enzymes from Aspergillus niger, Trichoderma harzianum, Pleurotus ostreatus IBL-02, Trametes versicolor IBL-04 and Schizophyllum commune IBL-06 using the similar 4 step purification protocol has also been reported [1, 19, 22, 23].

\section{Immobilization of $\mathrm{MnP}$}

Different experimental conditions were optimized for development of stable Ca-alginate beads. Varying concentrations of sodium alginate $(1-5 \%(\mathrm{w} / \mathrm{v}))$ were tried to get beads with desired mechanical strength. Sodium alginate at a concentration of $4 \%(\mathrm{w} / \mathrm{v})$ registered the highest immobilization efficiency of $73.15 \%$ (Fig. 1a).

A Na-alginate concentration of 3 to $4 \%$ has also been found suitable for protease immobilization [24]. At lower concentrations, the entrapped $\mathrm{MnP}$ leached out due to less tightly cross-linked alginate gel and greater pore size of the beads. Likewise, at increased Na-alginate concentration (> $4 \%$ ), the immobilization efficiency again declined 
Table 2 Purification of extracellular MnP from G. lucidum IBL-05

\begin{tabular}{llllll}
\hline Procedure & Total volume $(\mathrm{mL})$ & Total protein $(\mathrm{mg})$ & ${\text { Total activity }(\mathrm{UI})^{\text {a }}}$ & Specific activity $^{\text {b }}\left(\mathrm{UI}_{\mathrm{mg}^{-1}}\right)$ & Purification $^{\mathrm{c}}(\mathrm{fold})$ \\
\hline Crude extract & 300 & 1302.3 & 215220 & 165.3 & 1 \\
Ammonium Sulphate ppt. & 22 & 43.9 & 13501.4 & 307.5 & 1.86 \\
Dialysis & 21 & 39.2 & 12559.9 & 320.4 & 1.94 \\
DEAE-cellulose & 12 & 6.37 & 6811.2 & 1069.3 & 6.47 \\
Sephadex G-100 & 9 & 2.9 & 4599.1 & 1585.9 & 9.6 \\
\hline
\end{tabular}

${ }^{\mathrm{a}} \mathrm{Ul}$ is defined as the amount of enzyme converting $1 \mu \mathrm{mol}$ of substrate per minute.

${ }^{\mathrm{b}}$ Specific activity $=$ Ul per $\mathrm{mg}$ protein.

${ }^{c}$ Purification fold= Specific activity at given step/Specific activity of initial extract.

due to decreased gel porosity, high viscosity of the beads and substrate diffusion restrictions $[4,25]$. Similarly, higher the concentration of sodium alginate, the smaller the pore size of the beads leading to reduced immobilization efficiency [4].

The effect of $\mathrm{CaCl}_{2}$ concentration ( 1 to $2 \% \mathrm{w} / \mathrm{v}$ ) at $4 \%$ fixed Na-alginate concentration on immobilization efficiency was also investigated (Fig. 1b). Because alginate anions and $\mathrm{Ca}^{2+}$ cations are cross-linked to form Caalginate beads, it is expected that an increase in alginate or $\mathrm{CaCl}_{2}$ concentration will render it difficult for G. lucidum MnP to escape out from the gel network. However, the effect of $\mathrm{CaCl}_{2}$ on immobilization yield was very small in the tested range of $1-4 \%$. The excessive $\mathrm{Ca}^{2+}$ ions might not affect the formation of gel-like networks [4].

In next step, different MnP concentrations (0.2-0.7 $\mathrm{mg} / \mathrm{ml}$ ) were used. The results presented in Fig. 1c indicated a direct dependency of immobilization efficiency with increasing enzyme concentration up to $0.5 \mathrm{mg} \mathrm{MnP}$ per $\mathrm{ml}$ of alginate solution. Beyond this concentration, saturation in capacity of immobilization support occurs and immobilization efficiency declined slightly. Higher protein concentrations did not yield better immobilization, while the lower concentrations were not enough to saturate most of the enzyme binding sites on activated matrix [4].

The alginate beads size may be the most important parameter for optimal MnP immobilization. It was predicted that enzyme entrapped in smaller size beads showed higher immobilization efficiency due to reduced substrate transfer resistance. Alginate beads of different sizes $(1-3 \mathrm{~mm})$ were generated by changing the size of needle through which a mixture of $\mathrm{MnP}$ and alginate was dropped into $\mathrm{CaCl}_{2}$ solution. Fig. $1 \mathrm{~d}$ shows that 2 $\mathrm{mm}$ size beads furnished greater immobilization efficiency. As expected, the increased bead size leads to diminished immobilization yield of entrapped MnP. Other researchers have also reported the decline in activity of immobilized enzyme with increasing beads size due to mass transfer resistance [26].

The optimal immobilization conditions were $4 \%(\mathrm{w} / \mathrm{v})$ sodium alginate, $2 \%(\mathrm{w} / \mathrm{v}) \mathrm{CaCl}_{2}$ and $0.5 \mathrm{mg} / \mathrm{ml}$ enzyme concentration. Beads ( $2 \mathrm{~mm}$ diameter) developed under such conditions exhibited the maximum immobilized yield of $89.3 \pm 2.4 \%$.

\section{Characterization of free and Ca-alginate immobilized MnP}

A significant change in biochemical and kinetic parameters upon immobilization appraised the success of immobilization protocol. It is important to note that several factors can significantly affect the catalytic potential of ligninolytic enzymes. Among them, $\mathrm{pH}$, temperature and substrate concentration are the most relevant factors that not only affect enzyme activity but also reduce the stability if these are not at their optimum [27].

\section{Optimum pH}

The optimum $\mathrm{pH}$ for free and Ca-alginate immobilized MnP were found to be 5.0 and 4.0, respectively. Immobilization caused broadening of $\mathrm{pH}$ for immobilized $\mathrm{MnP}$ compared with free enzyme (Fig. 2). Moreover, Caalginate immobilized $\mathrm{MnP}$ displayed greater $\mathrm{pH}$-stability towards the acidic and alkaline changes in medium than its free counterpart. In previous reports, the maximum activities of MnPs from different WRF were observed to shift from alkaline to acidic $\mathrm{pH}$ [28]. Asgher and coworkers, [29] also observed similar shift in optimum $\mathrm{pH}$ for immobilized MnP.

\section{Optimum temperature}

The temperature-activity profiles of both native and $\mathrm{Ca}$ alginate bound $\mathrm{MnP}$ have been presented in Fig. 3. The optimum temperature for soluble $\mathrm{MnP}$ was $35{ }^{\circ} \mathrm{C}$ but immobilized $\mathrm{MnP}$ exhibited highest activity at $60{ }^{\circ} \mathrm{C}$. The hydrophobic and other secondary interactions might impair conformational flexibility requiring higher temperature for the enzyme molecule to reorganize and attain a proper conformation in order to maintain its reactivity [30,31]. Similar displacement in optimum temperature for immobilized enzyme has been reported in earlier studies where free $\mathrm{MnP}$ from Irpex lacteus showed maximum activity at $40{ }^{\circ} \mathrm{C}$ [32] and Ca-alginate bound ligninolytic enzyme was optimally active at $80{ }^{\circ} \mathrm{C}$ [7]. 


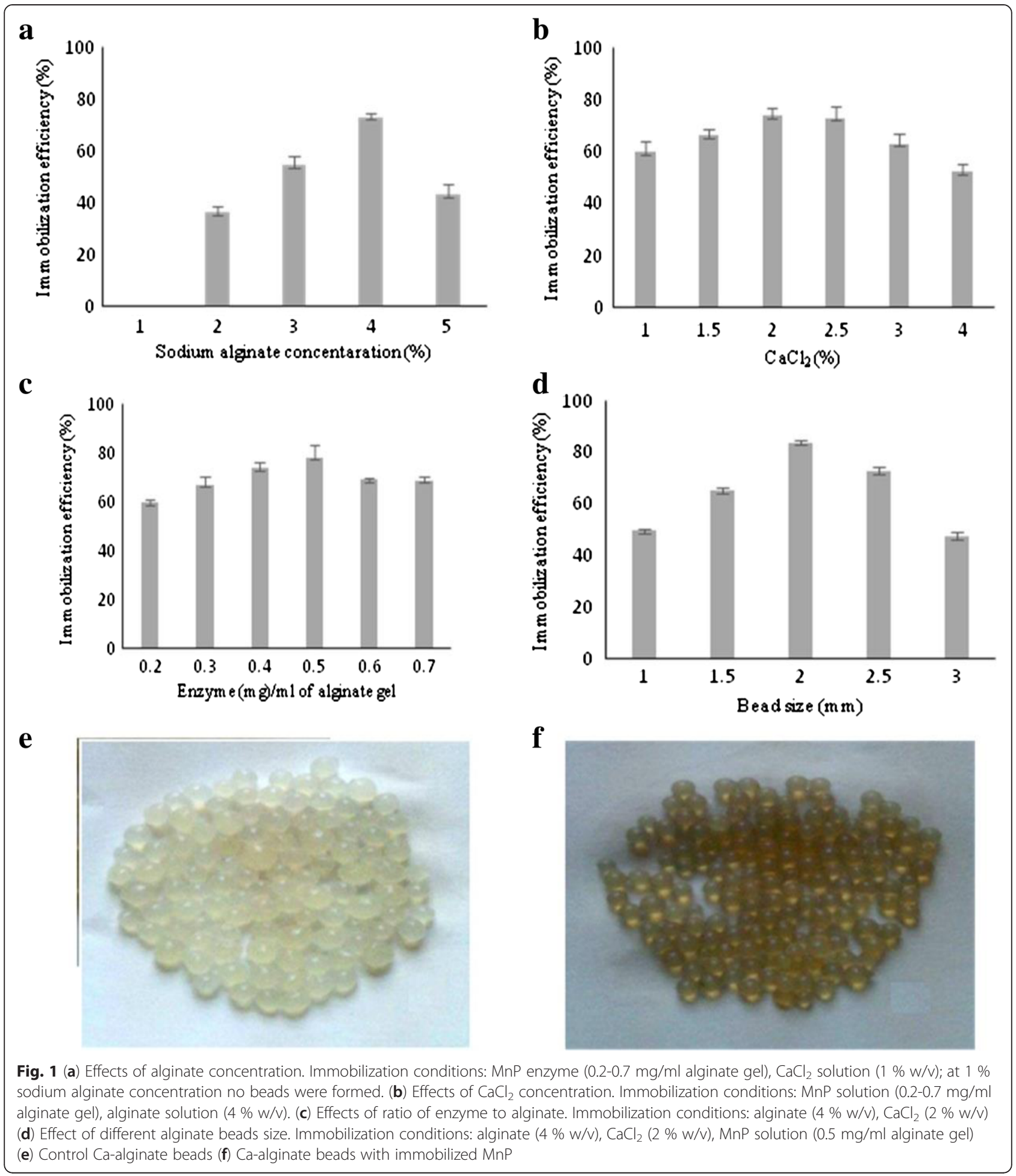

\section{Effect of substrate concentration: Determination of} $\mathrm{Km}$ and Vmax

Ca-alginate immobilized MnP showed lower substrate affinity, as confirmed by its higher $K_{\mathrm{m}}$ value $\left(K_{\mathrm{m}} ; 82 \mathrm{mM}\right)$ than that of free enzyme $\left(K_{\mathrm{m}}, 65.64 \mathrm{mM}\right)$ (Fig. 4); this was in agreement with other investigators reporting decreased affinity of immobilized MnP for substrate [29]. On the other hand, catalytic efficiency of immobilized MnP was enhanced $\left(V_{\max } ; 743 \mathrm{U} / \mathrm{ml}\right)$ as compared to free $\mathrm{MnP}$ $\left(V_{\max } ; 640 \mathrm{U} / \mathrm{ml}\right)$ that signifies the feasibility of immobilized system for myriad industrial applications. Similar findings indicating an increased $K_{\mathrm{m}}$ and $V_{\max }$ values 


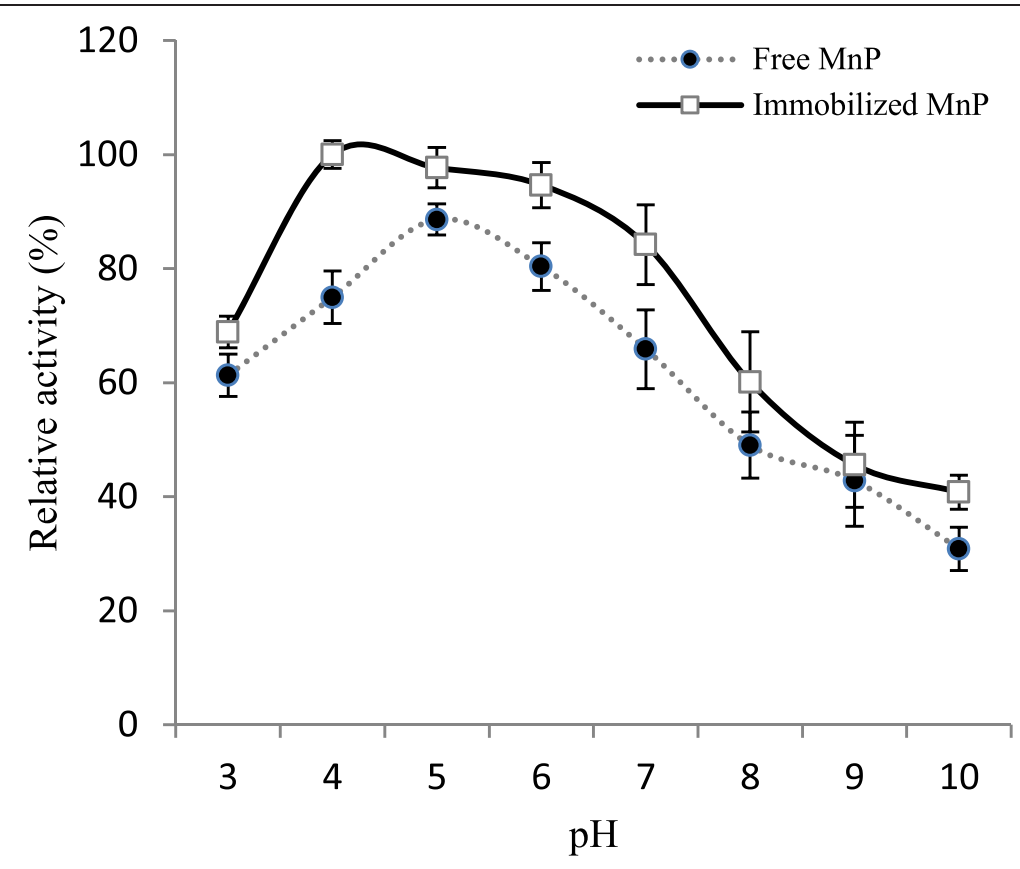

Fig. 2 Effect of $\mathrm{pH}$ on activities of free and Ca-alginate immobilized MnP

following entrapment in Ca-alginate beads have also previously been reported [33].

\section{Dyes decolorization with free and immobilized MnP}

The dye-decolorizing potential of free and immobilized $\mathrm{MnP}$ from G. lucidum was investigated against a set of five Sandal reactive dyes and results, thus obtained are presented in Fig. 5 (decolorization, \%). The color removal pattern with free and immobilized MnP was found to be significantly different. All tested dyes were more efficiently decolorized by immobilized $\mathrm{MnP}$ as compared to its free counterpart. In the presence of $\mathrm{MnSO}_{4}(1 \mathrm{mM})$ as redox mediator, a maximum decolorization efficiency of $61.9 \%$, $57.6 \%, 65.5 \%, 71.2 \%$ and $50.3 \%$ for Sandal-fix Red $\mathrm{C}_{4} \mathrm{BLN}$, Sandal-fix Turq Blue GWF, Sandal-fix Foron Blue $\mathrm{E}_{2} \mathrm{BLN}$, Sandal-fix Black CKF and Sandal-fix Golden

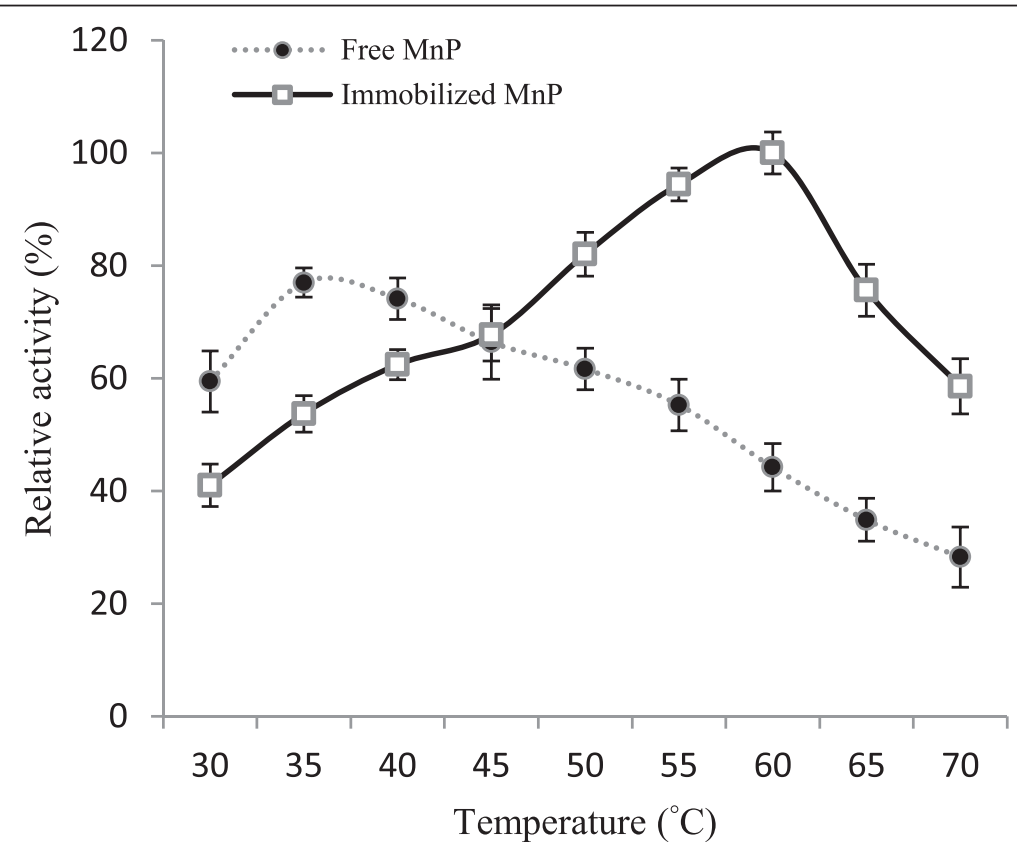

Fig. 3 Effect of temperature on activities of free and Ca-alginate immobilized MnP 


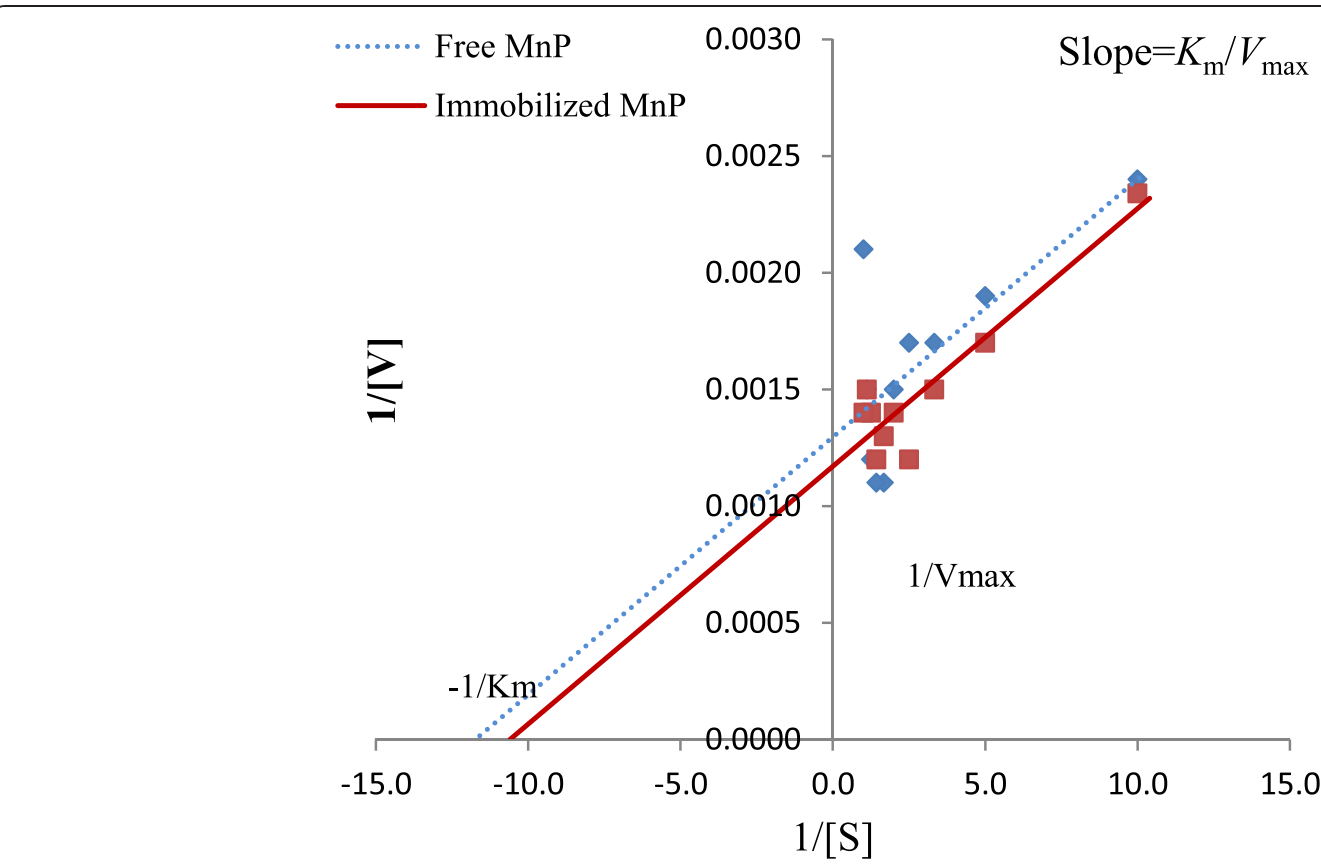

Fig. 4 Determination of $K_{\mathrm{m}}$ and $V_{\max }$ by Lineweaver Burk Plot: Standard quartz $\left(\mathrm{SiO}_{2}\right)$ cuvettes of $1 \mathrm{~mm}$ path length were used to calculate the values of kinetic parameters. Both free and immobilized $\mathrm{MnP}$ were incubated for $15 \mathrm{~min}$ at $30^{\circ} \mathrm{C}$ in sodium malonate buffer of $\mathrm{pH} 4.5$ before carrying out standard enzyme assay protocol. Lineweaver-Burk (Double reciprocal) plots were generated with Microsoft Excel Windows updated version 7 via nonlinear regression analysis using different concentrations (0.1-1.0 mM) of manganese sulphate as substrate at optimum pH and temperature conditions

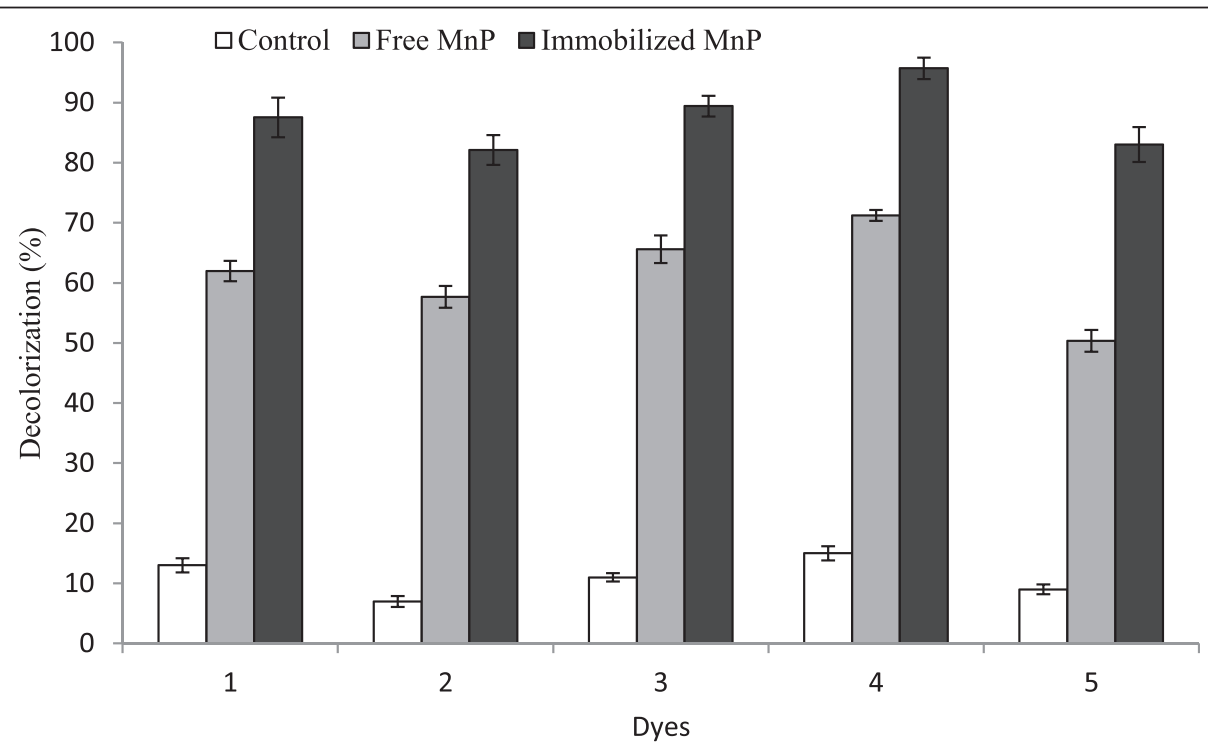

Fig. 5 Decolorization of Sandal reactive dyes (1) Sandal-fix Red C 4 BLN (2) Sandal-fix Turq Blue GWF (3) Sandal-fix Foron Blue E $E_{2} B L N$ (4) Sandal-fix Black CKF (5) Sandal-fix Golden Yellow CRL by free and Ca-alginate immobilized MnP. MnP decolorization reaction system contained; Na-malonate buffer (50 mM; pH 4.5), $0.1 \mathrm{mg} / \mathrm{ml}$ each dye solution, $10 \mathrm{~mL}$ free and $5 \mathrm{~g}$ of Ca-alginate-entrapped bio-catalyst (MnP), $1 \mathrm{~mL}$ of $1 \mathrm{mM} \mathrm{MnSO} \mathrm{m}_{4}$ as MnP mediator, $0.1 \mathrm{mM} \mathrm{H}_{2} \mathrm{O}_{2}$ to a total volume of $100 \mathrm{~mL}$. The flasks were incubated at $120 \mathrm{rpm}$ for $12 \mathrm{~h}$. Untreated dye solution containing all reagents and Ca-alginate beads without entrapped MnP enzyme was used as control 


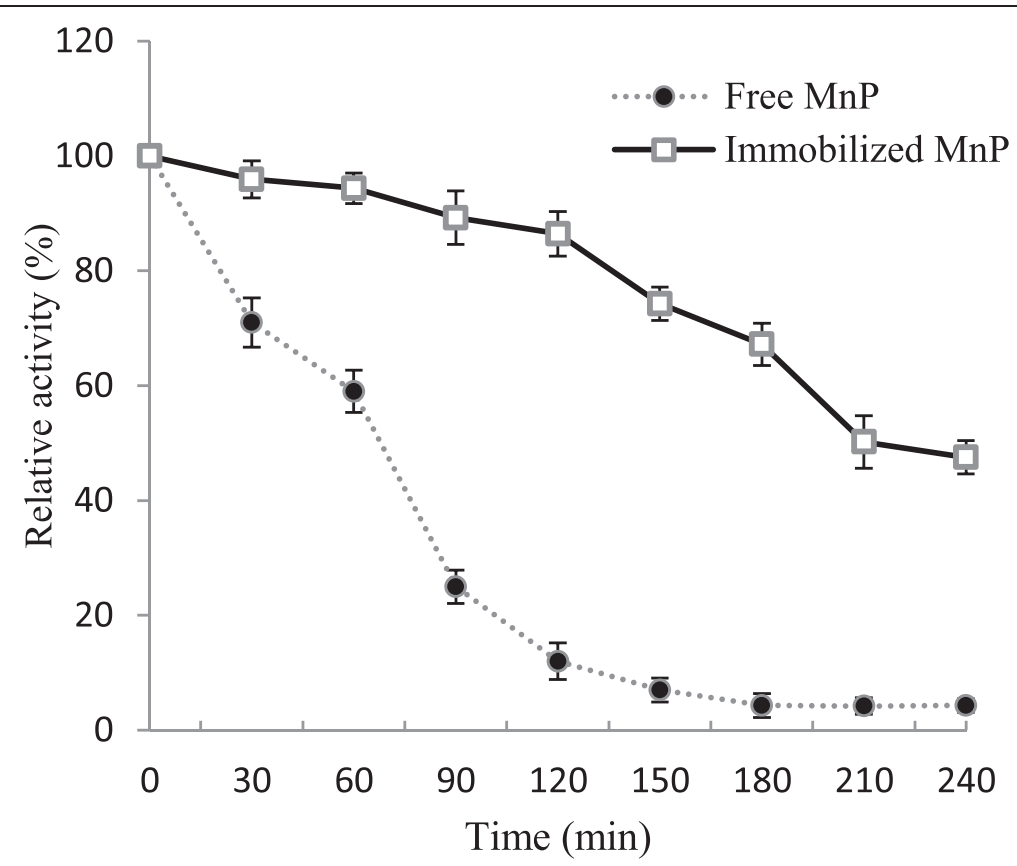

Fig. 6 Thermo-stability of free and immobilized MnP. MnP immobilized Ca-alginate beads were incubated in Na-malonate buffer solution (50 mM; $\mathrm{pH} 4.5)$ at $60^{\circ} \mathrm{C}$ for $240 \mathrm{~min}$. The residual activities were determined at different time intervals. The experiments were conducted in triplicate

Yellow CRL, respectively was achieved after $12 \mathrm{~h}$ with free MnP, whereas it increased to $87.5 \%, 82.1 \%, 89.4 \%, 95.7 \%$ and $83 \%$, respectively for Ca-alginate immobilized MnP. Immobilization prevents enzyme washouts and allows a high enzyme concentration to be maintained in a continuous reactor. Since the catalytic stability is often improved by immobilization, enzymes may degrade a higher concentration of toxic compounds then their free counterpart. Slight agitation $(120 \mathrm{rpm})$ of the beads favored rapid degradation, presumably caused by increased oxygen supply to the beads and ease translocation of substrate and products. Similar findings regarding Ca-alginate immobilized

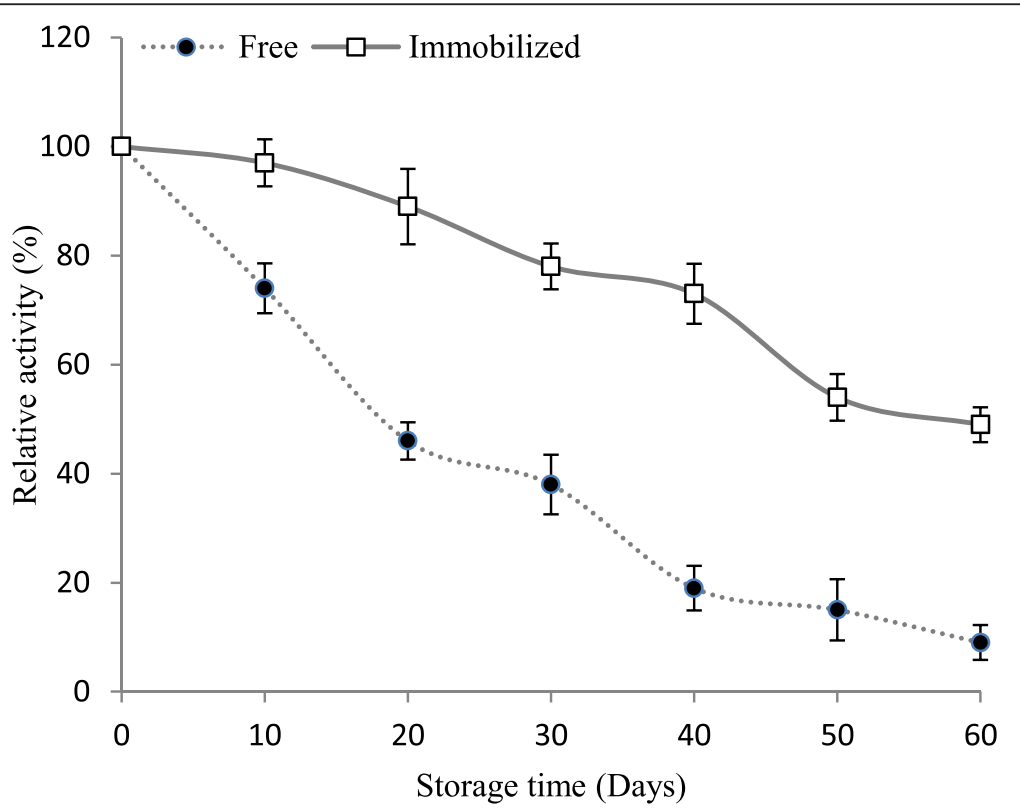

Fig. 7 Storage stabilities of free and Ca-alginate immobilized MnP. Free and immobilized MnPs were kept at $25^{\circ} \mathrm{C}$ for 60 days, and the activities were monitored from time to time under standard assay conditions. Enzyme activity prior to incubation was defined as $100 \%$. The experiments were performed in triplicate 


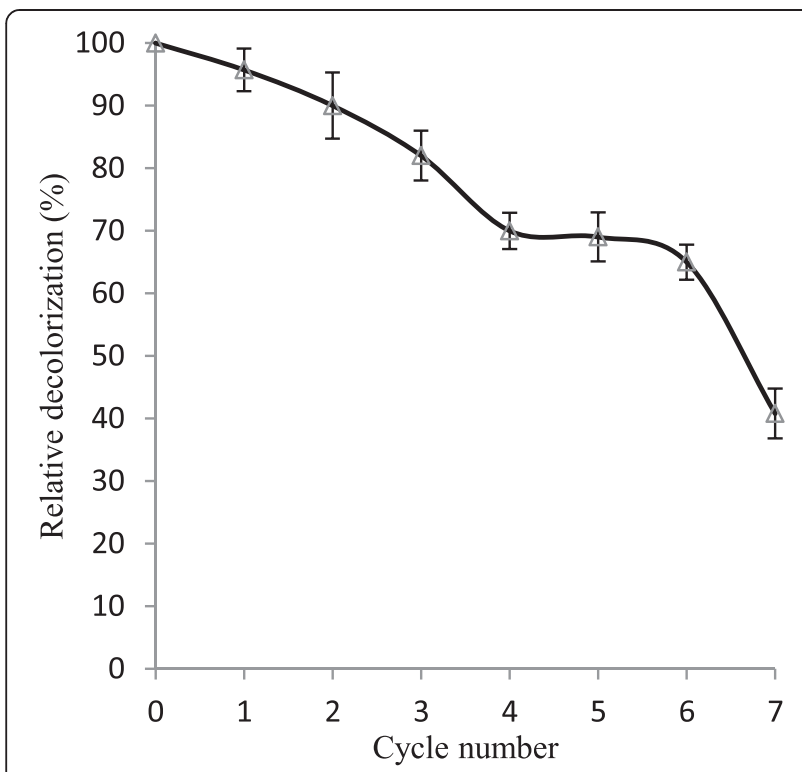

Fig. 8 Reusability of free and Ca-alginate beads immobilized MnP. Ca-alginate beads were used for 7 decolorization cycles of $12 \mathrm{~h}$ each. After each cycle, the beads were removed and washed with $50 \mathrm{mM}$ Na-malonate buffer and replaced with fresh dye solution. The activity of freshly prepared beads in the first run was defined as $100 \%$. The reusability study was performed in triplicate

ligninolytic enzymes and textile dyes decolorization were reported by Vishwakarma et al. [34] who achieved $99 \%$ decolorization efficiency of immobilized MnP for azo dyes after $18 \mathrm{~h}$ incubation. Peralta-Zamora et al. [35] decolorized four synthetic dyes in the range of 5-55\% within $30 \mathrm{~min}$ and Kunamneni et al. [36] found 61-82 \% decolorization of synthetic dyes in short contact time of $6 \mathrm{~h}$.

Generally, it is expected that dye removal using $\mathrm{Ca}$ alginate immobilized enzyme may be due to either enzymatic biodegradation or bioaccumulation/biosorption of the dye onto alginate beads [4]. In this study, to detect any possible removal of color due to dye adsorption onto the alginate beads, a control reaction with $\mathrm{Ca}$-alginate beads without bound $\mathrm{MnP}$ was prepared. It was observed that the alginate beads became colored especially after contacting with dyes. However Ca-alginate beads were able to remove only $7-15 \%$ color for all dyes. Thus, observation established that the predominant mechanism involved in dyes color removal was MnP biodegradation.

\section{Stability studies of immobilized MnP Thermal stability}

The thermal-stability of free and immobilized G. lucidum $\mathrm{MnP}$ was examined at $60{ }^{\circ} \mathrm{C}$ for different incubation times. After $120 \mathrm{~min}$, the free and immobilized $\mathrm{MnP}$ retained $12.0 \pm 3.8 \%$ and $86.45 \pm 3.2 \%$ of their initial activities, respectively. The residual activities at 240 min were recorded to be $4.3 \% \pm 1.2 \%$ for free $\mathrm{MnP}$ while $47.5 \pm 2.9 \%$ for immobilized MnP (Fig. 6). Similar to our findings, Daassi et al. [4] found that Ca-alginate immobilized C. gallica laccase showed $67 \%$ residual activity after $210 \mathrm{~min}$ incubation at $55^{\circ} \mathrm{C}$. From the results, it can be inferred that immobilized MnP was more stable as compared to its free counterpart.

\section{Storage stability}

The effect of storage on activities of free and entrapped $\mathrm{MnP}$ was investigated by incubating at room temperature $\left(25^{\circ} \mathrm{C}\right)$ for up to 60 days. Fig. 7 shows that, after 30 days of storage time, the free and immobilized MnP retained about $38.4 \%$ and $77.2 \%$ of their initial activities, respectively. Immobilization significantly enhanced the storage stability of Ca-alginate immobilized $\mathrm{MnP}$ that could be a valuable feature of this enzyme to be exploited for longer storage periods in industrial sectors. Previously, the activity of $\mathrm{Ca}$ alginate immobilized laccase was found to be $60 \%$ more than free laccase after 30 days storage [4].

\section{Reusability}

It was investigated whether the Ca-alginate-bound $\mathrm{MnP}$ could be successfully recycled in repeated batch operations. The reusability of $\mathrm{Ca}$-alginate beads immobilized $\mathrm{MnP}$ was investigated up to seven cycles and decolorization results are depicted in Fig. 8. The immobilized MnP retained more than $60 \%$ of its initial decolorization activity after five repeated cycles and $40 \%$ even after seven cycles. The gradual activity decline in the subsequent cycles could be correlated with enzyme inactivation. Upon frequent decolorization cycles, the substrate or product might cause blocking of some pores of beads that limit the access of dyes to the active site of entrapped MnP. However, Daassi et al. [4] highlighted that leakage of enzyme from alginate beads during washing after each cycle may lead to diminished activity. Similar observations of reusability have been documented previously [13]. The findings confirmed that $\mathrm{Ca}$-alginate beads immobilization appears as excellent strategy for $\mathrm{MnP}$ immobilization with greater efficiency and reusability for removal of toxic dyestuffs.

\section{Water quality parameters of MnP treated dyes}

The dye degrading efficacy of both free and Ca-alginate immobilized MnP was assessed on the basis of BOD, COD and TOC reduction, as shown in Fig. 9. It was observed that, the characteristic values of untreated tested dyes solution were beyond the permissible range set by the National Environmental Quality Standards (NEQS) for the safe discharge into sewage treatment facilities [37]. Biochemical (or Biological) oxygen demand (BOD) is a measure of how rapidly biological organisms consume oxygen in a water body. It can be considered as an indication of the quality of a water source. Before treatment, the BOD values were found in the range of $197.28-443.21 \mathrm{mg} /$ $\mathrm{L}$ for Sandal reactive dyes that reduced significantly after 


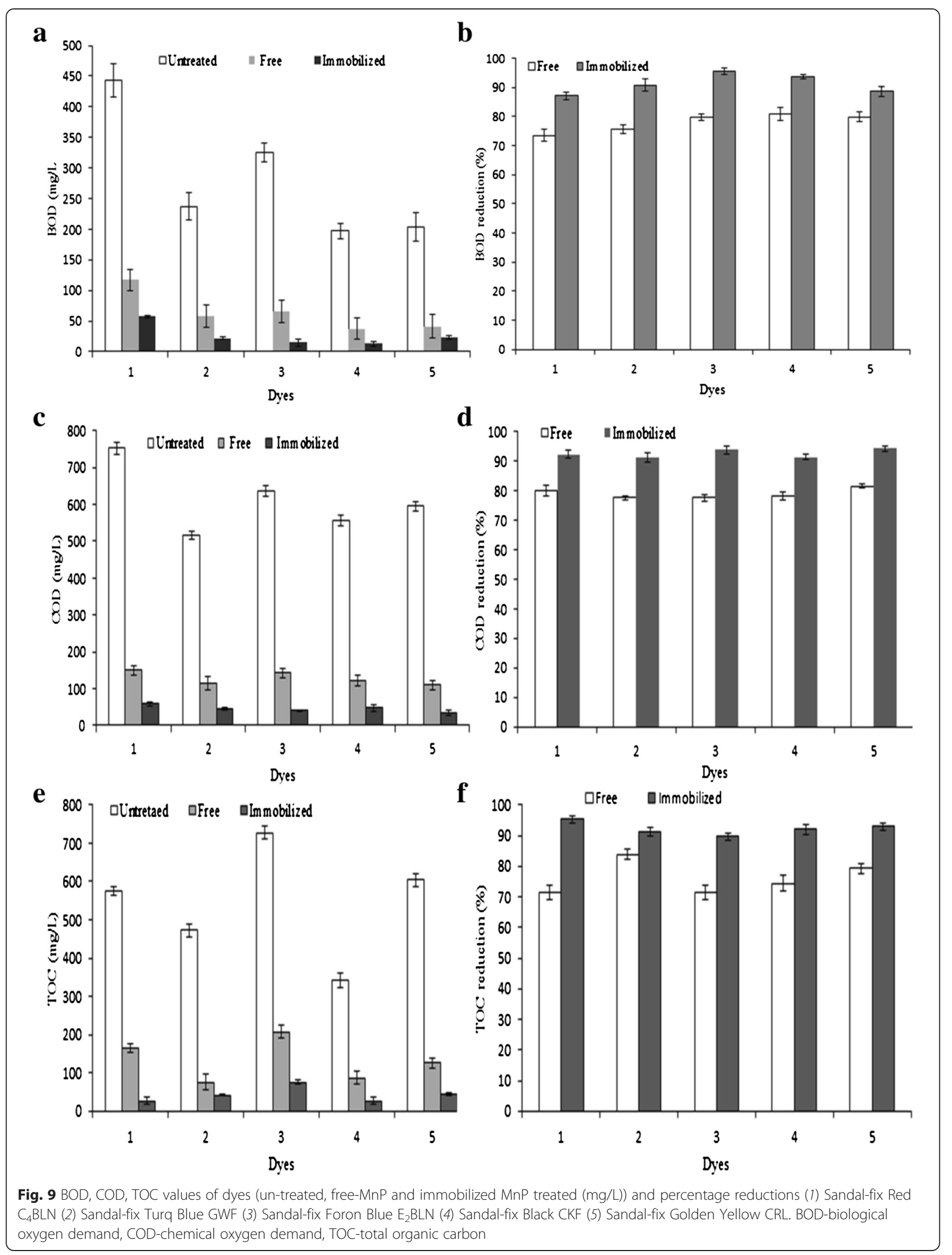



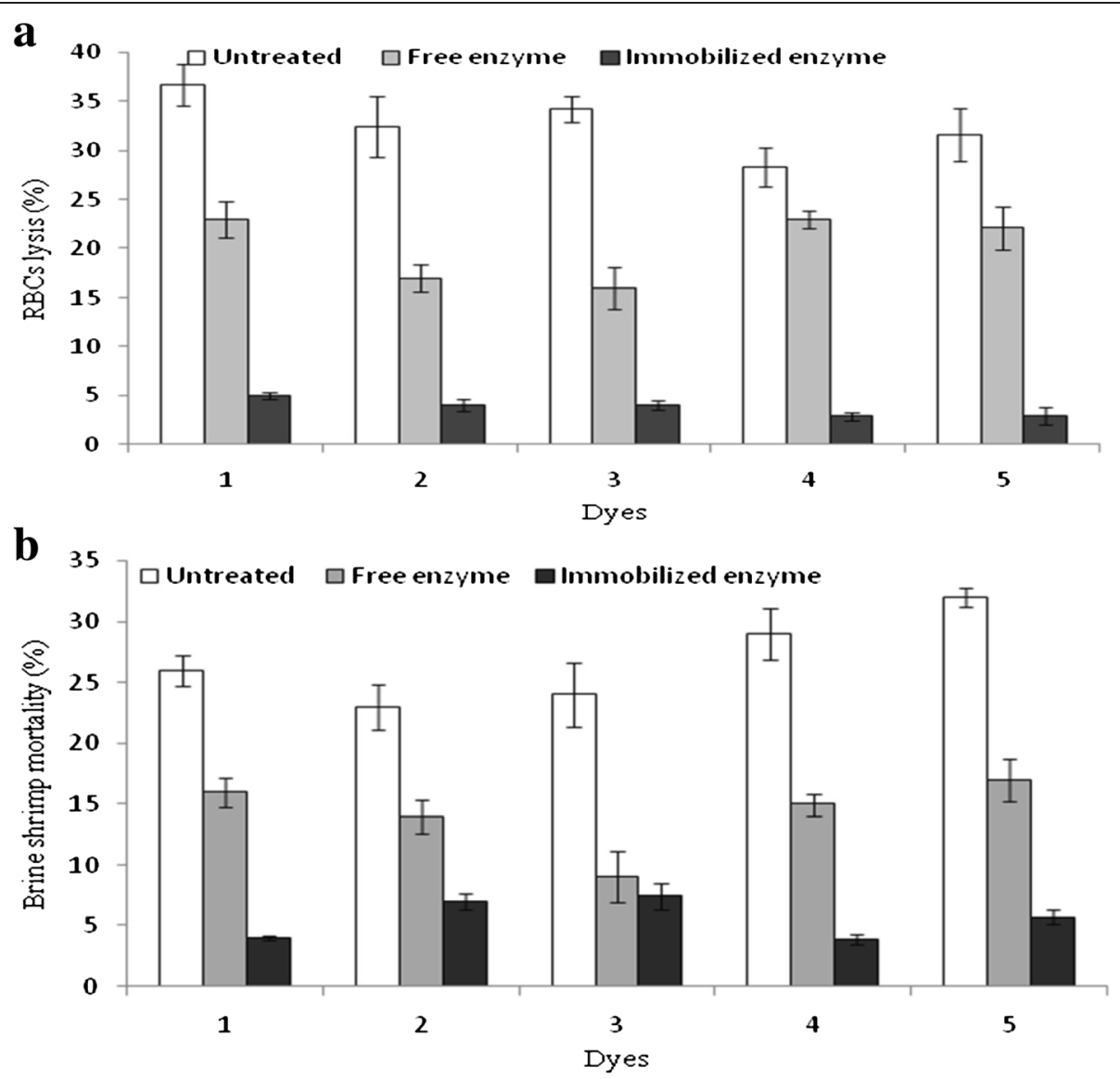

Fig. 10 Cytotoxicity of reactive dyes treated with free and Ca-alginate beads immobilized MnP. For heamolytic test, positive and negative controls were Triton X-100 (0.1\%) and phosphate buffer saline, respectively. For shrimp test, PC and NC were cyclophosphamide (10 g/mL) and sea water, respectively. The percentage increase or decrease of any parameters was calculated by computing the values before and after treatment

treatment with free and Ca-alginate immobilized $\mathrm{MnP}$ (Fig. 9a, b) BOD values of treated samples were in the range of permissible NEQ limits.

Chemical oxygen demand (COD) value is a useful measure of water quality that indicates the oxygen concentration required to oxidize all carbon compounds in a solution and is commonly used as an indirect measure of the amount of organic compounds present in wastewater. Figure $9 \mathrm{c}, \mathrm{d}$ indicates that the $\mathrm{COD}$ values were considerably reduced in enzyme treated dye samples. High COD reduction in the treatment of textile effluent by Pseudomonas species has also been reported [38] while, Pourbabaee et al. [39] also observed similar reductions in COD during bio-treatment of textile effluent by a newly isolated Bacillus sp. Previously, Agarry and Ayobami [40] reported that Pseudomonas fluorescence, Pseudomonas nigificans and Pseudomonas gellucidium, Aspergillus niger, Proteus morganii and Fusarium compacticum strains had good potential to remove color and degrade dyes, reduce COD and BOD levels between 39-48,74-97 and 77-95\%, respectively of the textile waste effluents with percent color removal.
A significant $(\mathrm{p} \geq 0.05)$ decrease in TOC values of treated dyes demonstrated the effectiveness of biological treatment to transform large xenobiotic recalcitrant molecule of dyes into simpler fragments. The percentage reductions in TOC were found to be 71.31-83.88 \% for free $\mathrm{MnP}$, which increased to $89.58-95.29$ \% for Ca-alginate immobilized MnP.

\section{Cytotoxicity reduction}

The cytotoxicity tests (heamolytic and brine shrimp lethality) were performed to evaluate the biological usefulness of free versus Ca-alginate immobilized $\mathrm{MnP}$, since these tests are frequently used for the toxicity screening of pollutants (air, soil and water) [5]. Before treatment, the cytotoxicity of dyes was in the range of 28.3-36.7 \% and 23-29 \% for erythrocyte lysis and brine shrimp, respectively. As illustrated in Fig. 10, after treatment with free MnP, the cytotoxicity values were in the range of $16-23 \%$ for erythrocytes lysis and $9-17 \%$ for brine shrimp. In case of Ca-alginate immobilized MnP, the cytotoxicity was reduced to $2.9-5 \%$ for erythrocytes lysis and $3.9-7.4 \%$ for brine shrimp, respectively. Several 
methods have been employed for the decolorization of dyes successfully; however, the toxicity is still a consideration of active research area because residues/degradation intermediates and end product might be more toxic than the parent compound [41]. It was confirmed that the dyes were not only decolorized but also detoxified by the action of immobilized MnP. Previously; up to $98 \%$ toxicity reduction of industrial effluents has been observed after treatment with WRF ligninolytic enzymes [42-44].

\section{Conclusions}

Ca-alginate beads served as an excellent supporting matrix for G. lucidum MnP immobilization. The immobilized MnP exhibited highest activity at $\mathrm{pH} 4$ and $60{ }^{\circ} \mathrm{C}$. The improved thermal stability, reusability and high activity presented by $\mathrm{Ca}$-alginate immobilized $\mathrm{MnP}$ would be the encouraging features. Besides, alginate exhibits many desirable characteristics, viz. biodegradability and biocompatibility, high gelling-ability, inexpensive and nontoxicity. Furthermore, subsequent exploitation of immobilized MnP for decolorization and detoxification of different textile reactive dyes makes it more valuable enzyme for various industrial applications. More efficient ligninolytic enzymes can be developed using advanced molecular or enzyme immobilization approaches to develop robust, stable and recyclable enzymes based technology for bioremediation of industrial effluents.

\footnotetext{
Abbreviations

MnP: Manganese peroxidase; WRF: White rot fungi; PDA: Potato dextrose agar; $\mathrm{H}_{2} \mathrm{O}_{2}$ : Hydrogen peroxide; BSA: Bovine serum Albumin; kDa: Kilo Dalton; SDS: Sodium dodecylsulphate; SSF: Solid state fermentation; DEAE-cellulsoe: Diethyl amino ethyl cellulose; TEMED: $N, \mathrm{~N}, \mathrm{~N}^{\prime}$, $\mathrm{N}^{\prime}$-tetra-methylethylenediamine; $\left(\mathrm{CaCl}_{2} \cdot 2 \mathrm{H}_{2} \mathrm{O}\right)$ : Calcium chloride dihydrate; BOD: Biochemical oxygen demand; COD: Chemical oxygen demand; TOC: Total organic carbon; NEQS: National Environmental Quality Standards.
}

\section{Competing interests}

The authors declare that they have no competing interests.

\begin{abstract}
Authors' contributions
MB (Research Associate of the project) carried out the experimental work on microbial cultivation, MnP production \& extraction, purification, Ca-alginate immobilization, kinetic characterization and decolorization and detoxification study of free and immobilized MnP. All the research work was carried out under the supervision of MA (Principal Investigator of the project) who designed and coordinated the experiments. MB and MA also interpreted the data and drafted the manuscript. Finally, both authors read and approved the final manuscript.
\end{abstract}

\begin{abstract}
Acknowledgements
The present study was a part of research project "Development of immobilized ligninolytic enzymes for industrial applications. We are highly grateful to the Higher Education Commission, Islamabad, Pakistan for financial support. We are also thankful to Dr. Muhammad shahid, UAF for providing assistance in toxicity studies.
\end{abstract}

Received: 29 May 2015 Accepted: 3 December 2015

Published online: 10 December 2015

\section{References}

1. Munir N, Asgher M, Tahir IM, Riaz M, Bilal M, Shah SMA. Utilization of agrowastes for production of ligninolytic enzymes in liquid state fermentation by Phanerochaete chrysosporium-IBL-03. IJCBS. 2015;7:9-14.

2. Asgher M, Yasmeen Q, lqbal HMN. Development of novel enzymatic bioremediation process for textile industry effluents through response surface methodology. Ecol Eng. 2014;63:1-11.

3. Daassi D, Rodriguez-Couto S, Nasri M, Mechichi T. Biodegradation of textile dyes by immobilized laccase from Coriolopsis gallica into Ca-alginate beads. Int Biodeter \& Biodegr. 2014;90:71-8.

4. Iqbal M, Bhatti IA, Zia-ur-Rehman M, Bhatti HN, Shahid M. Application of bioassays to evaluate the efficiency of advanced oxidation processes for the detoxification of industrial effluents. Asian J Chem. 2014;26:4291-6.

5. Mohajershojaei K, Mahmoodi NM, Khosravi A. Immobilization of laccase enzyme onto titania nanoparticle and decolorization of dyes from single and binary systems. Biotechnol Bioprocess Eng. 2015;20:109-16.

6. Lu R, Miyakoshi T. Studies on acetone powder and purified Rhus laccase immobilized on zirconium chloride for oxidation of phenols. Enzyme Res. 2012;12:8.

7. Mdaghri AS, Ghanam J, Merzouki M, Penninckx MJ, Benlemlih M. Immobilisation of Pycnoporus coccineus laccase in ca alginate beads for use in the degradation of aromatic compounds present in olive oil mill wastewaters. J Biotechnol Lett. 2013;4:91-4.

8. Bilal M, Asgher M. Sandal reactive dyes decolorization and cytotoxicity reduction using manganese peroxidase immobilized onto polyvinyl alcoholalginate beads. Chem Cent J. 2015;9:47.

9. Asgher M, Bhatti HN, Ashraf M, Legge RL. Recent developments in biodegradation of industrial pollutants by white rot fungi and their enzyme system. Biodegrad. 2008;19:771-83.

10. Patel Y, Gupte A. Biological Treatment of Textile Dyes by Agar-Agar Immobilized Consortium in a Packed Bed Reactor. Water Environ Res. 2015;87:242-51.

11. Yasmeen $Q$, Asgher M, Sheikh MA, Nawaz H. Optimization of ligninolytic enzymes production through response surface methodology. BioRes. 2013; 8:944-68.

12. Yinghui D, Qiuling W, Shiyu F. Laccase stabilization by covalent binding immobilization on activated polyvinyl alcohol carrier. Lett Appl Microbiol. 2002;35:451-6

13. Jamal F, Singh S, Qidwai T, Singh D, Pandey PK, Pandey GC, Khan MY. Catalytic activity of soluble versus immobilized cauliflower (Brassica oleracea) bud peroxidase-concanavalin A complex and its application in dye color removal. Biocatal Agric Biotechnol. 2013. http://dx.doi.org/10.1016/j.bcab. 2013.05.005.

14. Hernandez K, Fernandez-Lafuente R. Control of protein immobilization: Coupling immobilization and site-directed mutagenesis to improve biocatalyst or biosensor performance. Enz Microb Technol. 2011;48:107-22.

15. Blandino A, Macias M, Cantero D. Immobilization of glucose oxidase within calcium alginate gel capsules. Process Biochem. 2001;36:601-6.

16. Khani Z, Jolivalt C, Cretin M, Tingry S, Innocent C. Alginate/carbon composite beads for laccase and glucose oxidase encapsulation: application in biofuel cell technology. Biotechnol Lett. 2006;28:1779-86.

17. Wariishi H, Valli K, Gold MH. Manganese (II) oxidation by manganese peroxidase from the basidiomycete Phanerochaete chrysosporium. Kinetic mechanism and role of chelators. J Biol Chem. 1992;267:23688-95.

18. Bradford MM. A rapid and sensitive method for quantification of microgram quantities of protein utilizing the principle of protein dye binding. Anal Biochem. 1976;72:248-54

19. Bilal M, Asgher M, Ramzan M. Purification and biochemical characterization of extracellular manganese peroxidase from Ganoderma lucidum IBL-05 and its application. Sci Res Enz Essays. 2015;10:456-64.

20. Won K, Kim S, Kim K-J, Park HW, Moon S-J. Optimization of lipase entrapment in Ca-alginate gel beads. Process Biochem. 2005;40:2149-54

21. Noreen S, Asgher M, Hussain F, labal A. Performance improvement of Ca-alginate beads cross-linked laccase from Trametes versicolor IBL-04. BioRes. 2016;11:558-72

22. Ahmed I, Zia MA, Iftikhar T, lqbal HMN. Characterization and detergent compatibility of purified protease produced from Aspergillus niger by utilizing agro wastes. BioRes. 2011;6:4505.

23. Asgher M, Aslam B, lqbal HMN. Novel catalytic and effluent decolorization functionalities of sol-gel immobilized Pleurotus ostreatus IBL-02 manganese peroxidase produced from bio-processing of wheat straw. Chin J Catal. 2013;34:1756-61 
24. Geethanjali S, Subash A. Optimization and immobilization of purified Labeo rohita visceral protease by entrapment method. Enzyme Res. 2013. http://dx.doi.org/10.1155/2013/874050.

25. Blandino A, Macias M, Cantero D. Glucose oxidase release from Ca-alginate gel capsules. Enzyme Microb Technol. 2000;27:319-24.

26. Knezevic Z, Bobic S, Milutinovic A, Obradovic B, Mojovic L, Bugarski B. Alginate-immobilized lipase by electrostatic extrusion for the purpose of palm oil hydrolysis in lecithin/isooctane system. Process Biochem. 2002;38:313-8

27. Mukhopadhyay A, Dasgupta A K, Chakrabarti K. Enhanced functionality and stabilization of a cold active laccase using nanotechnology based activation-immobilization. Bioresour. Technol. 2015;179:573-84.

28. Baborova P, Moder M, Baldrian P, Cajthamlova K, Cajthaml T. Purification of a new manganese peroxidase of the white rot fungus Irpex lacteus and egrdatio of polycyclic aromatic hydrocarbons by the enzyme. Res Microbiol. 2006;157:248.

29. Asgher M, Kamal S, labal HMN. Improvement of catalytic efficiency, Thermostability and dye decolorization capability of Pleurotus ostreatus IBL-02 laccase by hydrophobic sol gel entrapment. Chem Cent J. 2012;6:110.

30. Ursoiu A, Paul C, Kurtan T, Peter F. Sol-gel entrapped Candida antarctica lipase B-A biocatalyst with excellent stability for kinetic resolution of secondary alcohols. Molecules, 2012;17:13045-61.

31. Munjal N, Sawhney SK. Stability and properties of mushroom tyrosinase entrapped in alginate, polyacrylamide and gelatin gels. Enz Microb Technol. 2002;30:613-9.

32. Shin K- S, Kim YH, Lim J-S. Purification and Characterization of manganese peroxidase of the white-rot fungus Irpex lacteus. J Microbiol. 2005;43:503-9.

33. Pal A, Khanum F. Covalent immobilization of xylanase on glutaraldehyde activated alginate beads using response surface methodology: Characterization of immobilized enzyme. Process Biochem. 2011:46:1315-22.

34. Vishwakarma SK, Singh MP, Srivastava AK, Pandey VK. Azo Dye (Direct Blue 14) Decolorization by Immobilized Extracellular Enzymes of Pleurotus Species. Cell Mol Biol. 2012;58:21-5.

35. Peralta-Zamora $P$, Pereira CM, Tiburtius ERL. Decolorization of reactive dyes by immobilized laccase. Appl Catal B. 2003;42:131-44.

36. Kunamneni A, Ghazi I, Camarero S, Ballesteros A, Plou FJ, Alcalde M. Decolorization of synthetic dyes by laccase immobilized on epoxy-activated carriers. Process Biochem. 2008:43:169-78.

37. Islam M, Mahmud K, Faruk O, Billah M. Textile dyeing industries in Bangladesh for sustainable development. Int J Environ Sci Develop. 2011:2:428-36

38. Olukanni O, Osuntoki A, Gbenle G. Textile effluent biodegradation potentials of textile effluent-adapted and non-adapted bacteria. Afr J Biotechnol. 2010;5:1980-4.

39. Pourbabaee A, Malekzadeh F, Sarbolouki M, Najafi F. Aerobic decoloriza-tion and detoxification of a disperse dye in textile effluent by a new isolate of Bacillus sp. Biotechnol Bioeng. 2006;93:631-5.

40. Agarry SE, Ayobami O. Evaluation of microbial systems for biotreatmentof textile waste effluents in Nigeria: biodecolourization and biodegradation oftextile dye. J Appl Sci Environ Manag. 2011;15:79-86.

41. Rane NR, Chandanshive W, Khandare RV, Gholave AR, Yadav SR, Govindwar SP. Green remediation of textile dyes containing wastewater by Ipomoea hederifolia L. RSC Adv. 2014:4:36623-32.

42. Sedighia M, Karimib A, Vahabzadeh F. Involvement of ligninolytic enzymes of Phanerochaete chrysosporium in treating the textile effluent containing Astrazon Red FBL in a packed-bed bioreactor. J Haz Mat 2009;169:88-93.

43. Iqbal HMN, Asgher M. Decolorization applicability of sol-gel matrix immobilized manganese peroxidase produced from an indigenous white rot fungal strain Ganoderma lucidum. BMC Biotechnol. 2013:13:56.

44. Verma P, Madamwar D. Production of ligninolytic enzymes for dye decolorization by cocultivation of white-rot fungi Pleurotus ostreatus and Phanerochaete chrysosporium under solid-state fermentation. Appl Biochem Biotechnol. 2002;102:109-18.

\section{Submit your next manuscript to BioMed Central and we will help you at every step:}

- We accept pre-submission inquiries

- Our selector tool helps you to find the most relevant journal

- We provide round the clock customer support

- Convenient online submission

- Thorough peer review

- Inclusion in PubMed and all major indexing services

- Maximum visibility for your research

Submit your manuscript at www biomedcentral.com/submit 